\title{
Legehelse - i Norge og Europa
}

For erfaringsdeling og felles forskningsprosjekter trenger vi samarbeid gjennom gode nettverk.

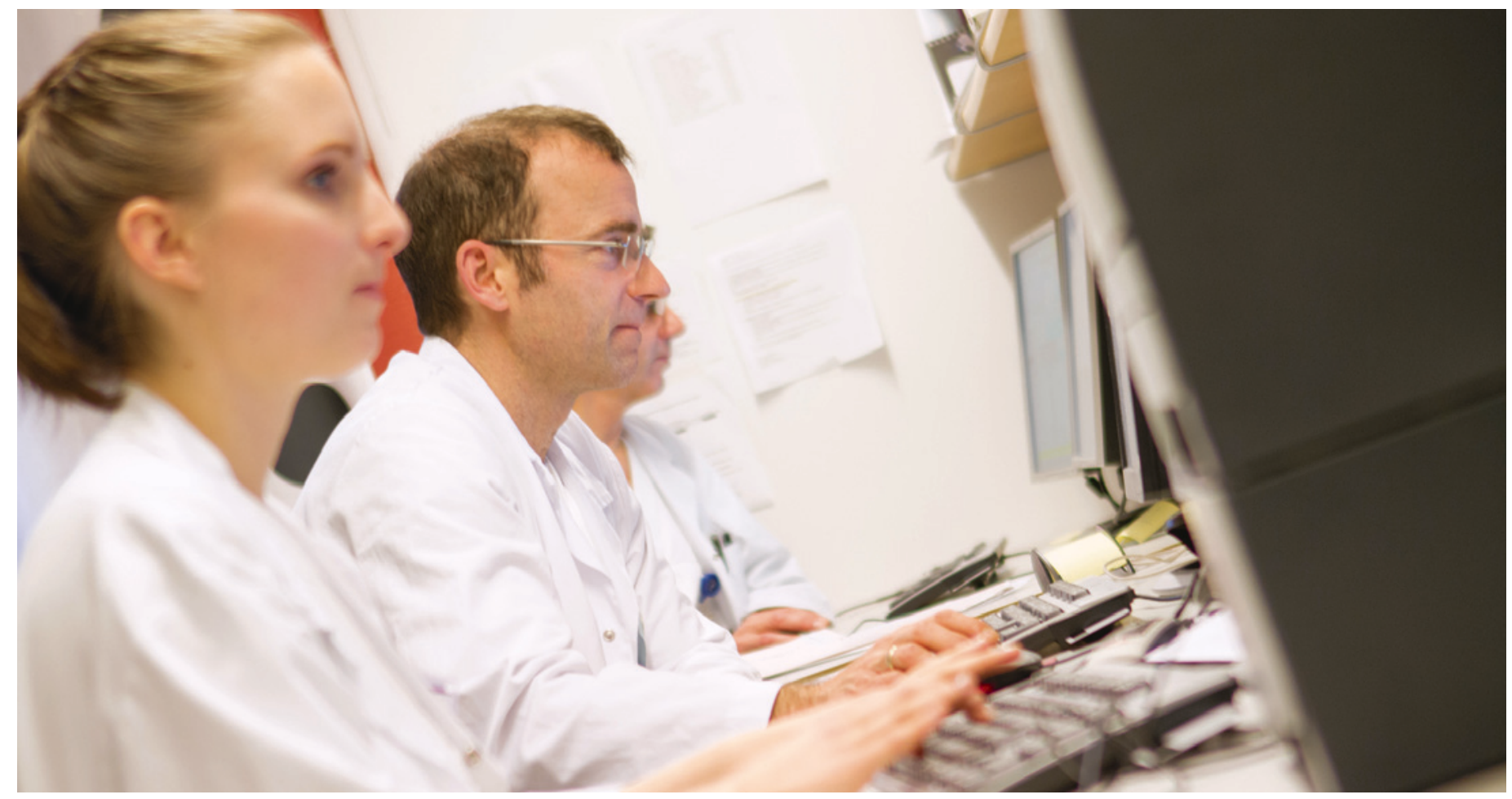

Illustrasjonsfoto: Ole Kristian Losvik

I Norge har Legeforeningen og stiftelsen Sykehjelps- og pensjonsordningen for leger (SOP) valgt å satse både på kollegiale støttetiltak for leger og på forskning om hvordan legers helse, helserelaterte atferd og arbeidskår kan ha betydning for legene selv og for kvalitet på pasientbehandlingen. På Legeforeningens nettsider finner man mer informasjon om støttetiltakene Støttekollegaordningen og Villa Sana: https://legeforeningen. no/Emner/Andre-emner/kollegastotte/, og på http://legeforsk.org/, LEFO - Legeforskningsinstituttets sider, kan man lese mer om forskningen.

Denne todelte tilnærmingen for å bedre legers helse og fungering, ved å fremme utviklingen av helse- og omsorgstilbudet for leger og ved å stimulere til forskning og erfaringsutveksling, vektlegges også i nettverksorganisasjonen European Association for Physician Health (EAPH). Den rekrutterer nå medlemmer fra et økende antall europeiske land.

\section{Å bygge nettverk}

Annethvert år organiserer European Association for Physician Health en konferanse, den første med Legeforskningsinstituttet som vert i Oslo i 2009. I april i år møttes nærmere 100 deltakere i Barcelona med temaet Legers resiliens. A bygge europeiske nettverk gjennom forskning og praksis.

Fra Wales ble et program for å styrke medisinstudenters evne til å håndtere utfordringer i løpet av studietiden presentert. Man utdanner og veileder «Student champions» fra hvert kull, som er tilgjengelige for medstudenter som vil ta opp krevende problemstillinger.

I Irland er man i ferd med å utvikle et nettbasert utdanningsprogram for leger og medisinstudenter om ivaretakelse av egen helse. I Spania har man undersøkt om kommunikasjonstrening for helsepersonell har betydning for tilfredshet, utbrenthet og resiliens hos leger. I Armenia, representert for første gang $\mathrm{i}$ år, undersøker man sammenhenger mellom legehelse og kvalitet i pasientbehandlingen. Ytterligere informasjon om European Association for Physician Health og presentasjoner fra konferansen finner man på www.eaph.eu.

Norge var godt representert på årets konferanse, med presentasjoner fra forskningsmiljøer ved Det medisinsk fakultet, Universitetet i Oslo, og fra Legeforskningsinstituttet. Dessuten deltok representanter fra
Legeforeningens utvalg for legehelse og fra Sykehjelps- og pensjonsordningen for leger.

Europeisk samarbeid er givende og krevende. Det å se mange likheter, men også betydelige forskjeller, i legers arbeidskår i land som ligger så nært hverandre, gir viktige perspektiver. Begreper som profesjon og autonomi kan ha forskjellige betydninger, og helsevesenets verdier varierer mellom land. Telefonmøter mellom oss som er valgt til å organisere konferansene, byr på både kulturelle og språklige utfordringer og muligheter. På denne måten bygger vi gode nettverk hvor vi kan dele erfaringer og samarbeide om forskningsprosjekter over landegrensene.

\section{Karin Isaksson Rø}

karin.ro@legeforeningen.no

Karin Isaksson Rø (f. 1962) er spesialist i arbeidsmedisin, ph.d. og instituttsjef ved LEFO - Legeforskningsinstituttet. Hun har siden 2011 vært styremedlem i European Association for Physician Health. 